\title{
Calcium Apatitie Deposition Disease: To Treat or Not to Treat in Athletes
}

\author{
Shalini Agarwal* \\ Department of Radio Diagnosis, Post Graduate Institute of Medical Sciences, India
}

Submission: June 01, 2018; Published: June 06, 2018

*Corresponding author: Shalini Agarwal, Department of Radio Diagnosis, Post Graduate Institute of Medical Sciences, India, Tel: +91 9355622099; Email: agarwalsdr@gmail.com

\section{Opinion}

Calcium apatite deposition disease is a common entity with an incidence of 6.8 to $54 \%$ [1,2]. They are commonly found in women between the ages of 30-60. However, cases have been reported in patients as young as 3 years old [3]. Radiographs can demonstrate these deposits in up to $7.5-20 \%$ of asymptomatic adults. Approximately half the cases become symptomatic [2]. When symptomatic, symptoms can vary from acute episodes of severe pain to chronic mild discomfort [3]. The dull aching pain in the chronic stage is disabling by itself. This can be quite disturbing for an athlete restricting his performance.

Based on the natural progression Uhthoff et al. [4] divided them into four stages: precalcific, formative, resorptive and post calcific. Similarly, Gartner divided them into 03 types depending on the border and the structure of the deposit [5]. Cho et al. [6] reported that on conservative treatment $46 \%$ of the calcific deposits by radiologic type had a tendency to become more cloudy and inhomogeneous than initial findings i.e. progress to Type II and Type III and $62 \%$ presented complete resolution or decrease in size [6]. De Witte et al. [7] found barbotage to be superior in cases of Type II and Type III calcification rather than Gärtner Type I calcification.

Treatment is generally conservative with immobilization with sling, non-steroidal anti-inflammatory drugs, and physical therapy. It is successful in up to $90 \%$ of patients [7]. However, in case of persisting and severe symptoms invasive treatments like corticosteroid injections, barbotage, extracorporeal shock wave therapy (ESWT), or surgery are applied [8]. Surgery is most effective, but it is associated with inherent complications, requires rehabilitation and is associated with higher costs. ESWT is useful, but it is painful [9]. Barbotage on the other hand is minimally invasive and painful and can be performed as an outpatient procedure. It can be done by using two needles or only a single needle. Some authors suggest aspiration, while the others do not. Cura et al. [8] found that the outcome of the patients in whom calcium was aspirated was not significantly different from that of patients in whom this was not the case.

This condition in athletes presents its own special problems. It is very clear that the treatment of this condition in the resorptive phase is most effective. However, the precalcific and the formative stage too present a problem in case of athletes. So far this has not been addressed in the literature and we need to look into it.

\section{References}

1. De Witte PB, Van Adrichem RA, Selten JW, Nagels J, Reijnierse M (2016) Radiological and clinical predictors of long term outcome in rotator cuff calcific tendinitis. European radiolog 26(10): 3401-3411.

2. Klontzas ME, Vassalou EE, Zibis AH, Karantanas AH (2016) Hydroxyapatiite deposition disease around the hip: outcomes of CTguided treatment. Diagnostic and interventional radiology 22(5): 466470 .

3. Beckman NM (2016) Calcium apatite deposition disease: Diagnosis and treatment. Radiol Res Pract 4801474: 16.

4. Uhtoff HK, Sarkar K, Maynard JA (1976) Calcifying tendinitis: A new concept of its pathogenesis. Clin Orthop Relat Res 118: 164-168.

5. Gartner J, Simons B (1990) Analysis of calcific deposits in calcifying tendinitis. Clin Orthop Relat Res 254: 111-120.

6. Cho NS, Lee BG, Rhee YG (2010) Radiologic course of the calcific deposits in calcific tendinitis of the shoulder: Does the initial radiologic aspect affect the final results? Journal of shoulder and elbow surgery 19(2): 267-272.

7. De Witte PB, Selten JW, Navas A, Nagels J, Visser CP, et al. (2013) Calcific tendinitis of the rotator cuff: A randomized controlled trial of ultrasound-guided needling and lavage versus subacromial corticosteroids. Am J Sports Med 41(7): 1665-1673.

8. Del Cura JL, Torre I, Zabala R, Legorburu A (2007) Sonographically guided percutaneous needle lavage in calcific tendinitis of the shoulder: Short and long-term results. AJR American journal of roentgenology 189(3): W128-134.

9. Speed CA, Hazleman BL (1999) Calcific tendinitis of the shoulder. The New England journal of medicine 340: 1582-1584. 
- Quality Editorial service

- Swift Peer Review

- Reprints availability

- E-prints Service

- Manuscript Podcast for convenient understanding

- Global attainment for your research

- Manuscript accessibility in different formats ( Pdf, E-pub, Full Text, Audio)

- Unceasing customer service

Track the below URL for one-step submission https://juniperpublishers.com/online-submission.php 